\title{
The Role of FeTi Addition to Micro-inclusions in the Production of ULC Steel Grades via the RH Process Route
}

\author{
Christian Bernhard', Philipp Dorrer', Susanne Michelic ${ }^{1}$, and Roman Rössler²
}

${ }^{1}$ Montanuniversitaet Leoben, Leoben, Austria

${ }^{2}$ voestalpine Stahl GmbH, Linz, Austria

Received September 2, 2019; accepted September 12, 2019; published online October 9, 2019

\begin{abstract}
In the production of ULC steel grades via the $\mathrm{RH}$ process route, $\mathrm{Al}$ is added first for deoxidation after the end of decarburization and FeTi follows after a certain period of separation of alumina particles and the related reduction of the total oxygen content. The FeTi addition is well known to cause clogging problems in the following casting process. The analysis of plant data by voestalpine Stahl in Linz indicates an increasing clogging tendency with a higher Ti/Al ratio in the steel. Automated SEM/EDS investigations on lollipop samples show the existence of a newly nucleated Ti-containing alumina particle population after the FeTi addition. These particles are comparably smaller than the alumina particles and, even if thermodynamically unstable, they still exist as a large population of small particles in samples taken from the tundish.

The addition of $\mathrm{Al}$ and $\mathrm{FeTi}$ into a molten steel sample with controlled initial oxygen activity for varying Ti/Al ratios was simulated in laboratory scale afterwards. Just like in the plant, a new population of small Ti-containing alumina particles nucleates, with the size and number depending on the $\mathrm{Ti} / \mathrm{Al}$ ratio in the melt.

Laboratory experiments and plant observations are in consistence with each other and indicate-for the underlying process route and process parameters-some countermeasures for the better control of clogging.
\end{abstract}

Keywords: Continuous Casting, Ti-ULC, Clogging
Der Einfluss der FeTi-Zugabe auf die Bildung mikroskopischer, nichtmetallischer Einschlüsse in ULC Stählen

Zusammenfassung: Die Produktion von Ti-stabilisierten ULC-Stählen sieht nach Tiefstentkohlung in der RH-Anlage die Desoxidation mit Aluminium und nach einer vorgegebenen Wartezeit, die Zugabe von FeTi vor, was nachfolgend zur Bildung von Anhaftungen im Gießsystem der Stranggießanlage ( „Clogging“) führen kann.

Die Auswertung von Betriebsdaten aus dem Stahlwerk der voestalpine in Linz zeigt eine deutlich höhere Clogging-Tendenz für zunehmendes Ti/AI-Verhältnis. REM/EDX-Untersuchungen an Lollipop-Proben nach der FeTi-Zugabe weisen auf die Existenz einer neu gebildeten Einschlusspopulation von kleinen Aluminiumoxiden mit geringem Ti-Gehalt hin. Obwohl thermodynamisch instabil, bleiben diese Partikel nahezu unverändert bis zum Vergießen erhalten und sind im Verteiler die bestimmende Einschlussklasse.

Die Zugabe von Al und FeTi zu einer Eisenschmelze mit kontrolliertem Anfangssauerstoffgehalt wurde anschließend im Labor simuliert. Auch unter diesen Bedingungen bilden sich Ti-haltige Aluminiumoxide, Zahl und Größe hängen von Anfangssauerstoffgehalt und dem Ti/Al-Verhältnis ab.

Aus den Untersuchungsergebnissen lassen sich qualitative Rückschlüsse auf mögliche Clogging-Gegenmaßnahmen ziehen.

Schlüsselwörter: Stranggießen von Stahl, Ti-stabilisierter ULC, Clogging

\section{Introduction}

Ti-stabilized ULC and IF steel grades frequently cause the build-up of oxide layers or oxide networks in the flow control system of the casting machine. This process is known as clogging and has a negative impact on the productivity and product quality. According to the extensive literature, different mechanisms, like chemical reactions be-

Ao. Univ. Prof. Dipl-Ing. Dr. C. Bernhard ( $\triangle 1)$

Montanuniversitaet Leoben,

8700 Leoben, Austria

christian.bernhard@unileoben.ac.at 


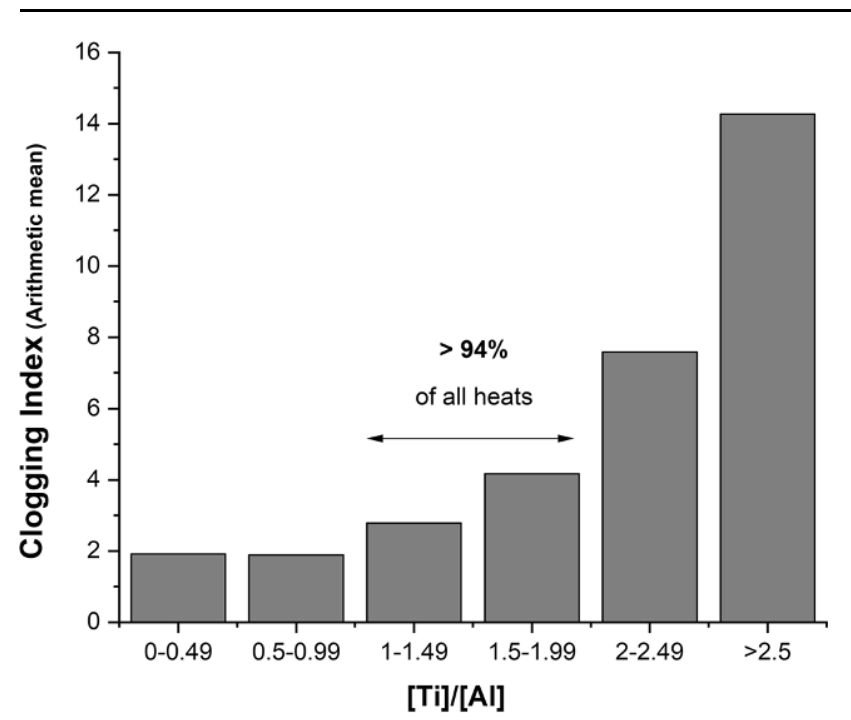

Fig. 1: Clogging index (according to the vaS internal definition) vs. Ti/AI ratio in the steel according to [3]

tween steel and refractories, the solidification of steel inside the submerged entry nozzle (SEN) or the adhesion of nonmetallic inclusions (NMI) on the inner surface of the SEN may trigger clogging. Clogging incidences, however, can commonly not be assigned to a single mechanism. In addition, differences in plant configurations, Al deoxidation and $\mathrm{FeTi}$ addition practices as well as the design of the fluid flow control system of the casting machine also have a significant influence on clogging (eg. [2]). This complexity of possible influencing parameters may contribute to the widely spread and partly inconsistent research findings on the clogging of Ti-stabilized ULC steel; a comprehensive overview of the state of knowledge was recently published by Dorrer et al. [3]. The present paper addresses only one of these aspects, namely the formation of a new inclusion population due to the $\mathrm{FeTi}$ addition after $\mathrm{RH}$ treatment as a possible cause for clogging.

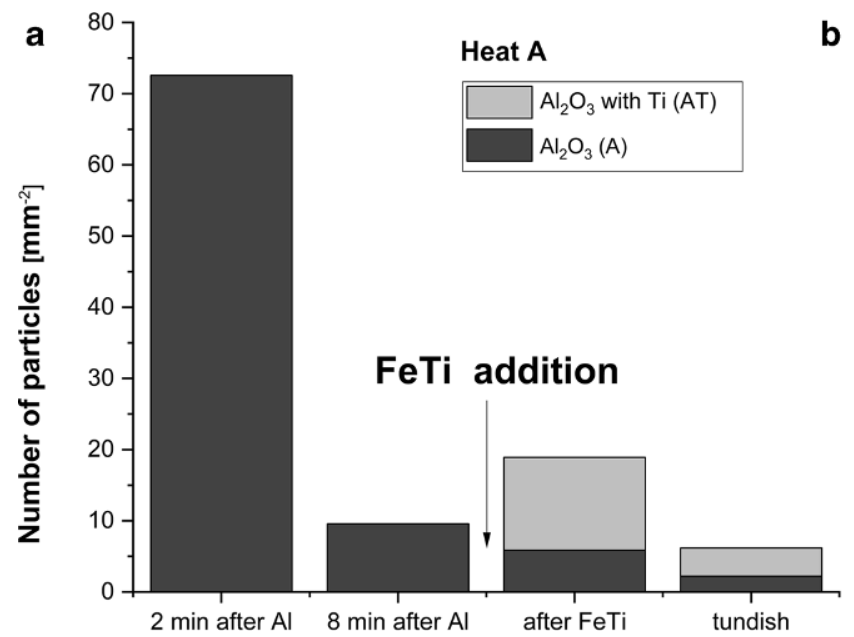

\section{Plant Observations}

Voestalpine Stahl GmbH (vaS) in Linz produces ULC steel grades typically in heat sizes of 180 tons via the BOF-LF-RH$\mathrm{CC}$ route. A general description of the production process can be found in [4]. After tapping with appr. 500 ppm oxygen and a possible temperature adjustment in the ladle furnace, degassing in the $\mathrm{RH}$ degasser starts. After achieving the target value for carbon, $\mathrm{Al}$ is added depending on the actual oxygen activity and the Al target value. During the next minutes, most alumina inclusions are separated, the total oxygen content decreases to less than $30 \mathrm{ppm}$ and finally $\mathrm{FeTi}$ is added. The slag still contains more than $15 \mathrm{wt}$. $\%$ of $\mathrm{FeO}$ at this time, and to minimize reoxidation, the ladle is transferred to the casting machine after a few minutes.

The negative influence of an increasing Ti/Al ratio on the clogging tendency has already been reported in two earlier publications $[5,6]$. Fig. 1 shows the vaS internal clogging index for more than 3000 heats, produced in the years 2017 and 2018 and graded according to the Ti/Al ratio of the produced steel. For the vast majority of these heats, the Ti/Al ratio ranges from 1 to 2 . The number of clogging incidences increases substantially with an increasing $\mathrm{Ti} / \mathrm{Al}$ ratio, but it should be mentioned that a higher Ti/Al ratio does not necessarily result in clogging. The Ti/Al ratio is therefore an indicator for increasing clogging sensitivity of a steel grade but not suitable as the only clogging criterion.

For a specific analysis of the evolution of the number, size, and morphology of inclusions over the time between $\mathrm{Al}$ addition and casting, samples taken from the production were analyzed by means of automated SEM/EDS. Representative of a large number of investigated heats, the results for two of them will be discussed exemplarily: Samples were taken $2 \mathrm{~min}$ and $8 \mathrm{~min}$ after Al addition, immediately after FeTi addition and from the tundish after casting of half of the heat. The final Ti/Al ratio amounts to 1.25 for Heat $A$ and to 1.65 for Heat B. Details on the sampling, metallographic/analytic investigations and classification of the inclusions can be found in [3].

Fig. 2 presents the detected number of inclusions containing alumina in the four samples for Heats $A$ and $B$.

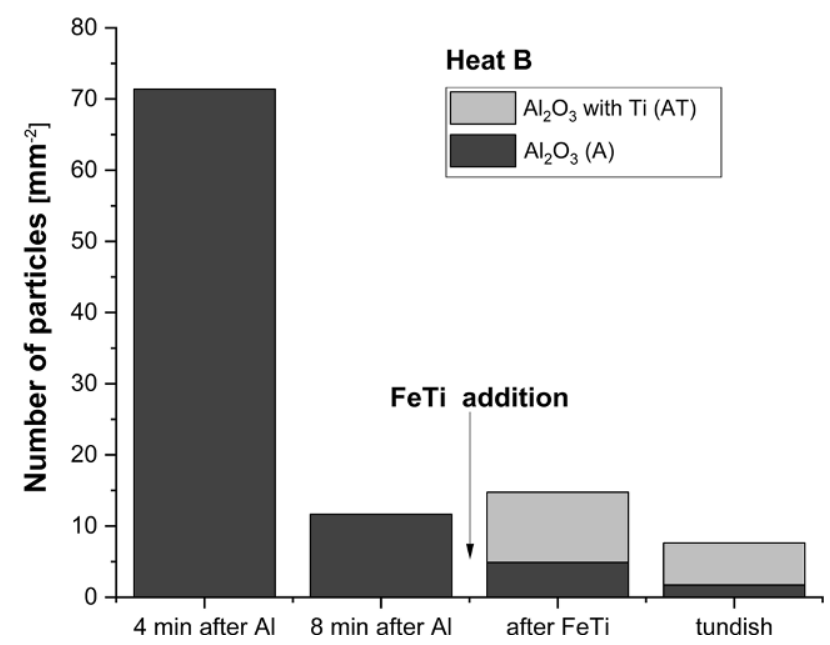

Fig. 2: Number of particles in samples taken from production process for Heats $A(\mathbf{a})$ and $B(\mathbf{b})$ 


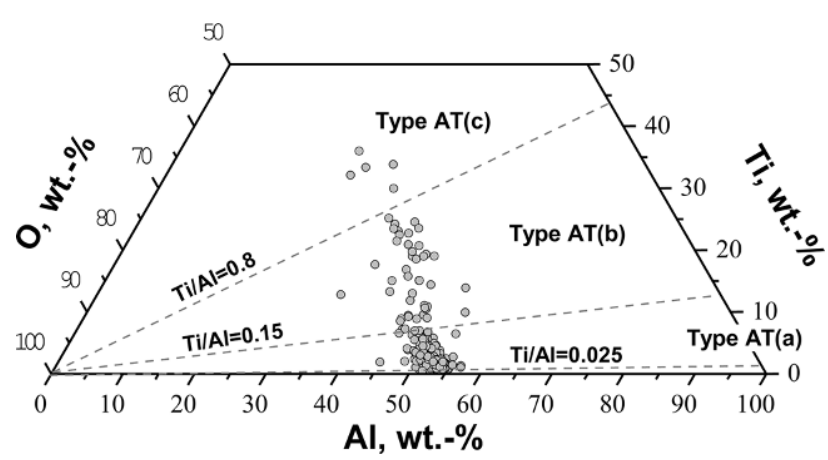

Fig. 3: Composition of particles of class "AT" (Heat A) in the ternary system Al-Ti-O

Two minutes after deoxidation, still a large number of alumina inclusions are present in both cases. The number decreases significantly during the next 6 min. After FeTi addition ( $8 \mathrm{~min}$ after deoxidation), a new type of inclusion can be detected, termed here as " $\mathrm{Al}_{2} \mathrm{O}_{3}$ with $\mathrm{Ti}^{\mathrm{i}}$ " or " $\mathrm{AT}$ " (consisting only of $\mathrm{Al}, \mathrm{Ti}, \mathrm{O}$ ). Between that point and the sample collection from the tundish, the greater part of the inclusions is again separated but Class AT survives and finally forms the majority of inclusions.

Fig. 3 shows the inclusions of Class AT from Heat A, ranging in the ternary system $\mathrm{Al}-\mathrm{Ti}-\mathrm{O}$ (in wt.-\%). The large majority of inclusions (appr. 80\%) is small, homogeneous and belongs to Class AT (a) with $0.025<\mathrm{Ti} / \mathrm{Al}<0.15$. Particles with higher Ti-content are mostly heterogeneous and contain phases with high $\mathrm{Ti}$ content $\left(\mathrm{TiO}_{2}\right.$ or $\left.\mathrm{Al}_{2} \mathrm{O}_{3} \cdot \mathrm{TiO}_{2}\right)$. The morphology of these inclusions is similar to inclusions as described in literature [7-9]. They might form as a result of the modification of inclusions between the time of FeTi addition and sampling in the tundish.

The particle diameter statistics (ECD) for Classes $\mathrm{Al}_{2} \mathrm{O}_{3}$ and $A T$ in tundish samples from Heats $A$ and $B$ show an aged population of $\mathrm{Al}_{2} \mathrm{O}_{3}$ particles with higher $\mathrm{ECD}$ (presumably resulting from deoxidation) and a population of small particles, pointing to the later nucleation, maybe due to the FeTi addition. For Class AT (a), all particles show a diameter of less than $3 \mu \mathrm{m}$, clearly indicating that they mostly nucleated after FeTi addition and are not the result of the modification of pre-existing oxides.

Former SEM/EDS investigations on clogged submerged entry nozzles after the casting of Ti-ULC steel grades indicate that the inclusions of Class AT are at least involved in the build-up of the clogging layer [5]. Therefore, lab experiments were performed to investigate the formation of inclusions of Class AT.

\section{Experimental Results}

The main objectives of the lab experiments were as follows:

- Adding Al and FeTi75 (5 min afterwards) to a steel melt with controlled initial oxygen content under Ar protection in $\mathrm{Al}_{2} \mathrm{O}_{3}$ crucibles without top slag to observe whether the population of AT inclusions forms due to the FeTi addition or not.
TABLE 1

Main parameters for the performed experiments according to [3]

\begin{tabular}{|c|c|}
\hline Test series & Main parameters \\
\hline $\begin{array}{l}\text { Series I } \\
\text { ( } 5 \text { experiments) }\end{array}$ & $\begin{array}{l}\text { Initial oxygen: } 140-170 \mathrm{ppm} \\
\text { Al: } 0.043-0.062 \text { wt.- } \% \\
\text { Ti/Al: } 0 / 0.8 / 0.9 / 1.89 / 1.93\end{array}$ \\
\hline $\begin{array}{l}\text { Series II } \\
\text { ( } 3 \text { experiments) }\end{array}$ & $\begin{array}{l}\text { Initial oxygen: } 127-176 \mathrm{ppm} \\
\mathrm{Al}: 0.016-0.033 \text { wt.- } \% \\
\text { Ti/Al: } 0.83 / 1.37 / 2.33\end{array}$ \\
\hline $\begin{array}{l}\text { Series III } \\
\text { ( } 3 \text { experiments) }\end{array}$ & $\begin{array}{l}\text { Initial oxygen: } 62-85 \mathrm{ppm} \\
\mathrm{Al}: 0.030-0.035 \text { wt.- } \% \\
\text { Ti/Al: } 0.56 / 1.28 / 2.30\end{array}$ \\
\hline
\end{tabular}

- Variation of initial oxygen content and the Ti/Al ratio to observe the influence on number and volume fraction of newly nucleated particles.

The lab experiments were conducted in a resistance heated furnace at $1600^{\circ} \mathrm{C}$ with $300 \mathrm{~g}$ of liquid iron, details can be found in [3]. The initial oxygen content was adjusted to target values of 60,120 , and $150 \mathrm{ppm}$ by adding an Fe-O master alloy with $0.18-0.20$ wt.- $\%$ O. The Ti/Al ratio was gradually changed between no FeTi addition and $\mathrm{Ti} / \mathrm{Al}=2.3$. The main parameters for the experiments performed are given in Table 1. The FeTi75 used contains between 0.1 and 0.3 wt.- $\%$ of oxygen and is highly heterogeneous.

In the following, only the results of automated SEM/EDS on the very last sample taken ( $8 \mathrm{~min}$ after FeTi addition) is considered for the discussion. Fig. 4 summarizes the results of Series I: Class AT is detected in all samples with FeTi addition, and the number of AT particles grows with increasing $\mathrm{Ti} / \mathrm{Al}$ ratio and the size of the AT particles (here the mean ECD) is significantly smaller than in the class $A$.

Fig. 5 compares the results from experiments in the range of $\mathrm{Ti} / \mathrm{Al}=1.37-1.93$ and different initial oxygen content with the results for Heats $A$ and $B$ from the plant observations. The significant influence of an increasing oxygen content is obvious.

The following conclusions can be drawn from the experimental results:

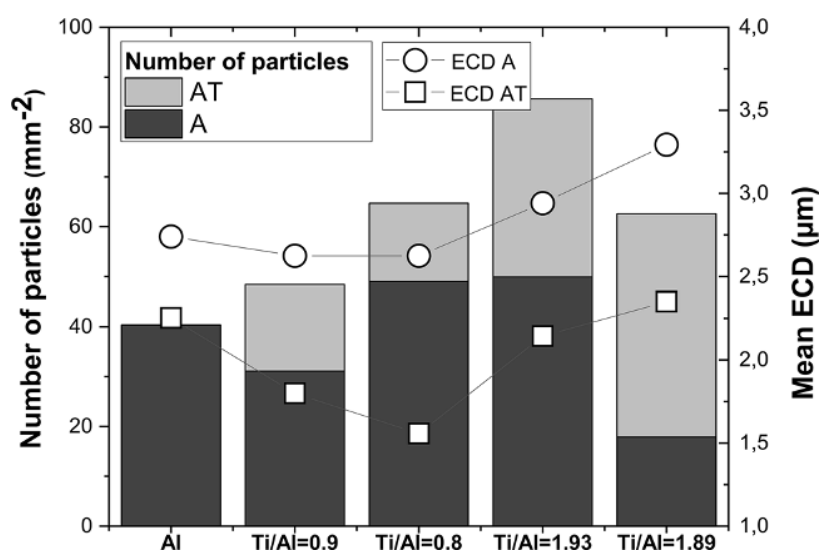

Fig. 4: Number of particles in classes " $A$ " and "AT" with mean ECD for experiments of series I 


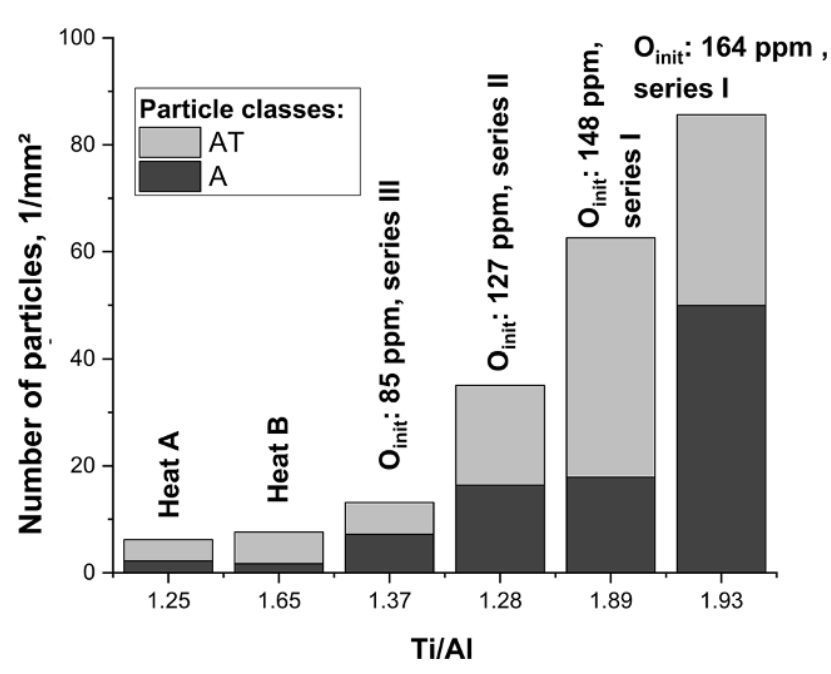

Fig. 5: Number of particles in classes " $\mathrm{A}$ " and "AT" versus Ti/Al and gradually increasing initial oxygen content

- Despite the exclusion of slag and air as oxygen sources, the FeTi addition results in the nucleation of a new population of Class AT.

- Initial oxygen content and Ti/Al ratio are the main influencing factor for the final number and volume fraction of AT inclusions.

- Even though the AT inclusions are thermodynamically unstable, they show no tendency to modify their shape or chemistry during the 8-minute holding time after the FeTi addition.

- The wetting behavior between ULC steel and AT inclusions is very similar to pure $\mathrm{Al}_{2} \mathrm{O}_{3}$. The high number of small AT particles should be attracted by the submerged entry nozzle and result in a higher tendency towards clogging $[10,11]$.

It should be noted that both the separation and agglomeration tendencies are rather small in the experiments as fluid flow in the melt only results from natural convection and in addition, thermal gradients are marginal. The separation of particles is limited to the adhesion at the crucible/steel interface. The significance of the results is limited to the above-listed conclusions and the results should not be interpreted with respect to the behavior of particles in a ladle.

\section{Conclusion}

Plant observations and laboratory experiments suggest the nucleation of a new inclusion population of $\mathrm{Al}_{2} \mathrm{O}_{3}$ particles with traces of $\mathrm{Ti}$ after $\mathrm{FeTi}$ addition. According to the understanding of the interfacial physics between steel and refractory in the fluid flow control system of casting machines, these particles will be attracted by the interface and as they are small and their number is high, they should increase the risk of clogging. It should not be concluded that a higher Ti/Al ratio is the only decisive parameter for clogging; nor is the adhesion of oxides by the interface the only clogging mechanism involved. Nevertheless, the control of $\mathrm{O}$ input by the added FeTi could be a beneficial measure for clogging prevention.

Funding. The authors gratefully acknowledge the funding support of K1MET GmbH, metallurgical competence centre. The research program of the competence centre K1-MET is supported by COMET (Competence Centre for Excellent Technologies), the Austrian program for competence centres. COMET is funded by the Federal Ministry for Transport, Innovation and Technology, the Federal Ministry for Digital and Economic Affairs, the provinces of Upper Austria, Tyrol, and Styria, and the Styrian Business Promotion Agency. Beside public funding, the project is financed by the industrial partners voestalpine Stahl, voestalpine Stahl Donawitz and RHI Magnesita, Austria.

Funding. Open access funding provided by Montanuniversität Leoben.

Open Access This article is distributed under the terms of the Creative Commons Attribution 4.0 International License (http://creativecommons. org/licenses/by/4.0/), which permits unrestricted use, distribution, and reproduction in any medium, provided you give appropriate credit to the original author(s) and the source, provide a link to the Creative Commons license, and indicate if changes were made.

\section{References}

1. Bernhard, C.; Dorrer, P.; Michelic, S.K.; R. Roessler: The role of FeTi addition to micro-inclusions in the production of ULC steel grades via the $\mathrm{RH}$ process route; 4th European Steel Technology and Application Days, Duesseldorf, Germany, 2019

2. Lyons, C.; Kaushik, P.: Inclusion Characterization of Titanium Stabilized Ultra Low Carbon Steels: Impact of Oxygen Activity before Deoxidation; steel research int., 82 (2011), No. 12, pp. 1394-1403

3. Dorrer, P.; Michelic, S.K.; Bernhard, C.; Penz, A., Roessler, R.: Study on the Influence of FeTi-Addition on the Inclusion Population in TiStabilized ULC Steels and Its Consequences for SEN-Clogging; steel research int., 2019, https://doi.org/10.1002/srin.201800635

4. Jungreithmeier, A.; Pissenberger, E.; Burgstaller, K.; Mörtl, J.: Proc. ISSTech Conf. 2003, Indianapolis, Indiana, 2003, pp. 227-240

5. Bernhard, C.; Xia, G.; Karasangabo, A.; Egger, M.; Pissenberger, A.: Investigating the influence of $\mathrm{Ti}$ and $\mathrm{P}$ on clogging of ULC steel in the continuous casting process, 7th European Continuous Casting Conference (ECCC), Dusseldorf, Germany, 2011

6. Bernhard, C.; Xia, G.; Egger, M.; Pissenberger, A.; Michelic, S.: Experimental investigation into the influence of $\mathrm{Ti}$ on the clogging of ULC steels in continuous casting, AISTech 2012, Paper A 294, Atlanta, USA, 2012

7. Matsuura, H.; Wang, C.; Wen, G.; Sridhar, S.: The transient stages of inclusion evolution during $\mathrm{Al}$ and/or Ti additions to molten iron, ISIJ Int. (47) 2007, No. 9, pp. 1265-1274

8. Wang, C.; Matsuura, H.; Kikuchi, N.; Sridhar, S.: Experimental simulation of the role of $\mathrm{Ti}$ on transient reactions in Al-killed Fe melts, Rev. Met. Paris, 105 (2008), pp. 22-32. https://doi.org/10.1051/metal: 2008010

9. Sun, M. K.; Jung, I.-H.; Lee, H. G.: Morphology and chemistry of oxide inclusions after $\mathrm{Al}$ and Ti complex deoxidation, Metals Materials Int., 14 (2008), pp. 791-798

10. Dieguez Salgado, U.; Weiß, C.; Michelic, S.K.; Bernhard, C.: Fluid Force-Induced Detachment Criteria for Nonmetallic Inclusions Adhered to a Refractory/Molten Steel Interface, Met. Mat. Trans. B, 49 (2018), pp. 1632-1643

11. Dieguez Salgado, U.: Investigation of particle attraction by steel/ refractory and steel/gas interfaces and the associated relevance for clogging in casting processes, PhD, Montanuniversitaet Leoben, July 2018

Publisher's Note. Springer Nature remains neutral with regard to jurisdictional claims in published maps and institutional affiliations. 